\title{
風作用下での越波量の出現頻度に関する実験的研究

\author{
Experimental Study on Frequency Distributions of Wave-Overtopping Quantity \\ under Windy Conditions
}

\author{
山城 賢 $^{1} \cdot$ 改田将平 ${ }^{2} \cdot$ 知念 卓 $^{3} \cdot$ 吉田明徳 ${ }^{4}$
}

\author{
Masaru YAMASHIRO, Shohei KAIDA, Suguru CHINEN and Akinori YOSHIDA
}

\begin{abstract}
Authors have developed a measurement technique using Particle Image Velocimetry(PIV) for the purpose of accurate measurement of individual wave-overtopping volumes in two dimensional wind-wave flume experiments. In order to clarify the characteristics of appearance frequencies of individual wave-overtopping volumes for a vertical seawall, model experiments were conducted generating irregular waves and winds at the same time. The main conclusions are as follows: 1) Frequencies of large wave-overtopping increase as the wind becomes stronger. Probability Density Functions for normalized wave-overtopping volumes, however, are constant and agree with an exponential distribution with the expected value of 1.0. 2) Mean wave-overtopping volume can be estimated from wave overtopping rate.
\end{abstract}

\section{1.はじめに}

不規則波中の個別波の越波量は, 時間平均量である越 波流量に比べて相当に大きくなることがあり，沿岸防災 を考えるうえで, 越波流量だけでなく, 個別波の越波量 の出現頻度を把握することの重要性が指摘されている. 越波量の出現頻度に関する既往の研究例は幾つかあり, 井上ら $(1989,1990)$, Franco ら (1994), Victorら （2012）は，水理模型実験を行い，個別波の越波量（あ るいは個別波の越波流量）が 2 母数あるいは 3 母数の Weibull分布で表されることを示し, 各母数と構造物や波 浪の条件との関連を検討している。また，泉宮ら（2006） および泉宮（2009）は消波護岸における越波の現地観測 結果から個別波の越波流量の出現頻度が, 形状母数が1 のWeibull分布，つまり指数分布に適合することを示し， 理論的にも妥当であることを説明している。このように, 個別波の越波量の出現頻度に関する知見は蓄積されつつ あるといえる。

ところで, 現実に越波が生じる状況を考えると, 通常 は強風が作用していることから，風が作用する状況での 越波の出現特性を明らかにすることが望まれる。しかし ながら，越波流量に対する風の影響を検討した例はあっ ても，これまでに風作用下に扔ける越波量の出現頻度に ついて検討された例はないと思われる，実際にそのよう な検討を行うには，風洞装置を備えた造波水路を用いた

\begin{tabular}{|c|c|c|}
\hline 1 正会員 & 博 (工) & 九州大学助教 大学院工学研究院附属 \\
\hline 2 学生会員 & & $\begin{array}{l}\text { 九州大学大学院工学府海洋システム工学 } \\
\text { 専攻 }\end{array}$ \\
\hline & & 沖縄県庁 \\
\hline 正会員 & 工博 & $\begin{array}{l}\text { 九州大学特任教授 大学院工学研究院 } \\
\text { 工学系国際交流支援室 }\end{array}$ \\
\hline
\end{tabular}

水理模型実験が有効な手段と考えられるが，一般的に， 模型実験であっても個別波の越波量を計測することは難 しく, 現在においても確立された方法はない. 加えて, 風洞内に風の妨げにならないよう計測機器を設置して, 個別波の越波量を計測することは，な抢さら難しい。こ のような観点から, 著者らは, 水理模型実験により強風 作用下での不規則波に扔ける越波量の出現頻度を検討す ることを目的に，画像解析を用いた越波量の計測手法を 提案し，これまでに，風と不規則波を同時に作用させる 越波実験を行って提案した計測手法の有用性について検 討した（山城ら，2012a，2012b)。本研究では, 直立堤 で打ち上がる越波を対象に，本計測手法により得られた 実験結果に基づいて，風が作用する状況での不規則波に よる越波量の出現頻度の特性を明らかにした。

\section{2. 計測手法と実験内容}

\section{（1）越波量計測手法の概略}

本計測手法では，図-1に示すように断面2 次元造波風 洞水路に設置された護岸模型の前面での流体運動（波の 打上げや越波）を可視化し，高速度カメラで撮影する。 撮影した映像から PIV（Particle Image Velocimetry）によ り流速べクトルを求める. 図-2にPIVによる解析結果を 示す。この流速べクトルから, 護岸天端の高さに設けた 検査ライン上の鉛直流速の時系列を抽出する。得られた 流速の時系列を検査ラインについて積分すれば，検査ラ インを上下に通過する水量の時系列が得られ，さらに 1 周期間で積分すれば, 1 波当りの正味の越波量が求めら れる。このとき，ある 1 波の作用時間は，護岸の壁面に 沿って計測した水位変動デー夕から判断する.

越波のような複雑な現象の場合, PIV 結果に計測誤差 や久測が生じやすく, 流速デー夕に対し何らかの補正が 


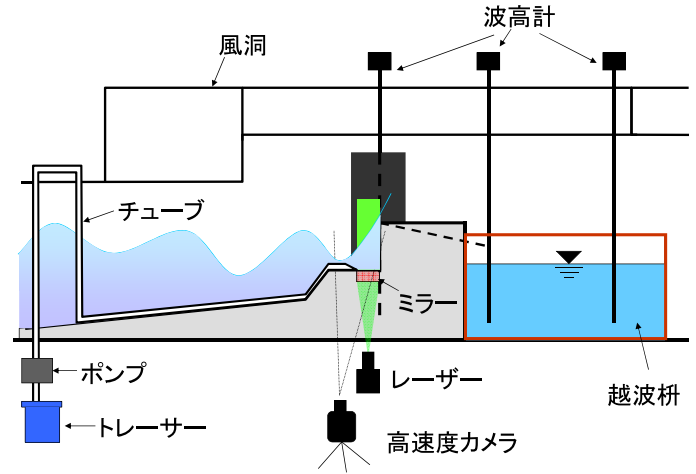

図-1 可視化実験の概略
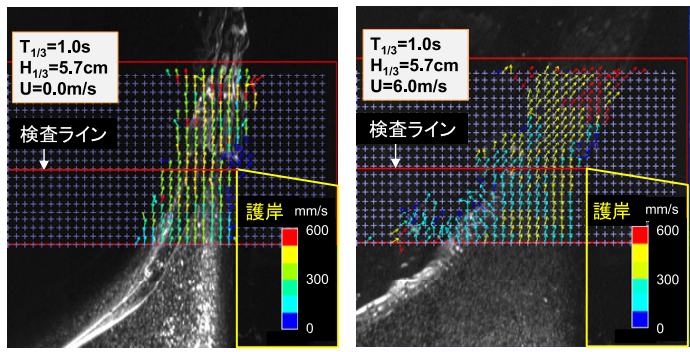

図-2 PIVによる解析結果の例（左：無風，右：風速 $6.0 \mathrm{~m} / \mathrm{s}$ )

必要となる，本計測手法では2 段階の補正を行う。第 1 段階では, 前後のデータからかけ離れた異常值を検出し 前後のデー夕の平均值で置き換える. 第2 段階の補正で は，基準となる累積越波量のデー夕を使用するため，実 験の際に，図-1に示すように護岸模型の背後に越波妌を 設置し妌内の水位変化を計測しておく，越波妌では個別 波の越波量の計測は困難であるが，全体的な増加過程で ある累積越波量の時間変化は妥当に得られる。これを利 用し, PIVから求めた累積越波量が越波杵で計測した累 積越波量と全体的に一致するように，越波量算定の元で ある流速デー夕を補正する。

本計測手法は, 単に越波量を求めるだけでなく, 構造 物前面での流体運動そのものを計測するため, 例えば, 天端から打ち上がる水量, 護岸前面に戻る水量, 打ち上 がる水塊や越波水の速度などを得ることができる.

\section{（2）実験条件}

実験は，図-3に示す断面二次元造波風洞水路（長さ $28 \mathrm{~m}$, 高さ $0.5 \mathrm{~m}$, 幅 $0.3 \mathrm{~m})$ に海底斜面および直立堤の模 型を設置して行った。トレーサーにはマイクロバブルを 使用し, グリーンレーザーシートを照射して可視化した。 高速度カメラ（株)ライブラリー製 GV200）の撮影条件は フレームレート $400 \mathrm{fps}$ ，シャッター速度 $1 / 500 \mathrm{~s}$ である。 入射波は修正Bretschneider-光易型スペクトルを有する 2 種類の不規則波で，有義波高をそれぞれ $\mathrm{H}_{1 / 3}=4.5 \mathrm{~cm}$ 拉よ び $5.7 \mathrm{~cm}$ ，有義波周期はともに $\mathrm{T}_{1 / 3}=1.0 \mathrm{~s}$ と設定した。風

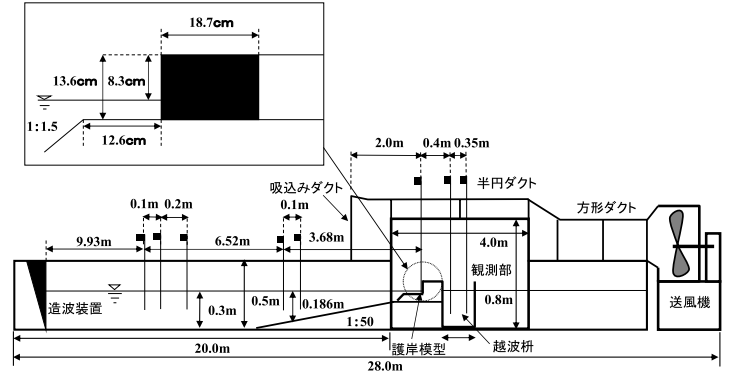

図-3 断面二次元造波風洞水路

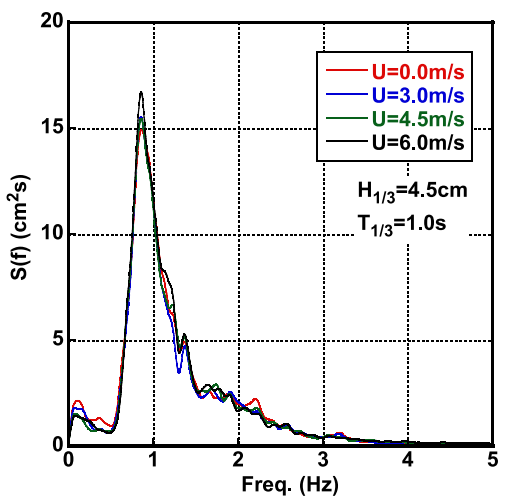

図-4 護岸前面の水面変動のスペクトル $\left(\mathrm{H}_{1 / 3}=4.5 \mathrm{~cm}, \mathrm{~T}_{1 / 3}=1.0 \mathrm{~s}\right)$

の条件は, 護岸壁面の位置での静水面上 $20 \mathrm{~cm}$ と $30 \mathrm{~cm}$ （それぞれ天端上 $11.7 \mathrm{~cm} ， 21.7 \mathrm{~cm}$ ）における風速を平均 したものを代表風速として， $0.0 \mathrm{~m} / \mathrm{s}$ （無風）， $3.0 \mathrm{~m} / \mathrm{s}$, $4.5 \mathrm{~m} / \mathrm{s}, 6.0 \mathrm{~m} / \mathrm{s}$ を設定した。各実験ケースとも波と風を 同時に約 470 秒間作用させ，その間，高速度カメラによ る撮影を行った。

同時に, 越波升内の 2 か所および護岸壁面の 1 か所を 含む水路内の計 8 か所で水面変動を波高計によりサンプ リング周波数 $10 \mathrm{~Hz}$ で記録した. デー夕数は 4696 個であ る.なお, PIV解析には市販のソフトウェア (株ディテ クト製Flownizer2D）を使用した．また，可視化の詳細， および前述の越波量の算定と補正手順の詳細について は，山城ら（2012b）を参照されたい。

(3) 予備的検討

\section{a) 風の波への影響}

越波に対する風の影響を調べるうえでは，風が越波水 のみに作用し，できるだけ波には影響しないことが望ま れる。 そのため本実験においては, 護岸模型上の風速が 安定するために必要な最小限の風洞設置範囲を模型から 沖側に $2.0 \mathrm{~m}$ とて，その範囲にのみ風洞を取り付けた (図-3参照)。また，風速についても波への影響を考元 $6.0 \mathrm{~m} / \mathrm{s}$ までとした。この設定が妥当であるか確認するた め, 護岸前面の水位変動を調べた。図-4に有義波高 $\mathrm{H}_{1 / 3}=4.5 \mathrm{~cm}$ のケースに抢ける護岸前面の水位変動のスペ 


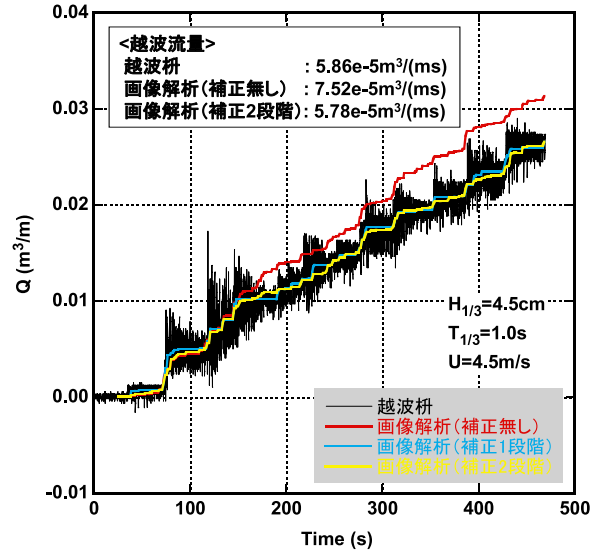

図-5 累積越波量の比較 $\left(\mathrm{H}_{1 / 3}=4.5 \mathrm{~cm}, \mathrm{~T}_{1 / 3}=1.0 \mathrm{~s}, \mathrm{U}=4.5 \mathrm{~m} / \mathrm{s}\right)$

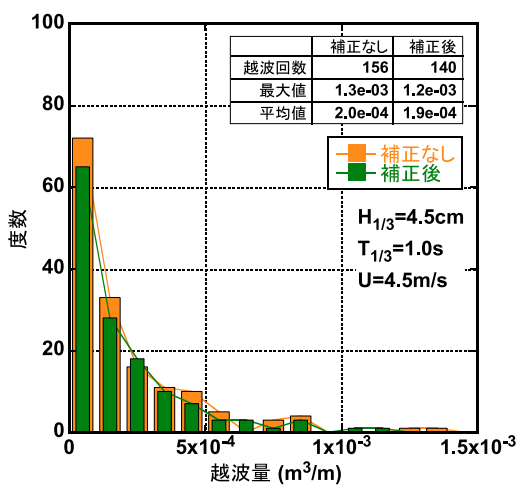

図-6＼cjkstart流速補正の出現頻度への影響

クトルを示す。風洞内では風により短周期の波が発生し， 風速が大きくなるほど顕著になる，図より，水位変動の スペクトルはほぼ同一であり，風による顕著な短周期成 分は認められない，したがって，本実験の範囲では，波 に対する風の影響は小さいと考えられる.

\section{b）流速補正の効果と越波量出現頻度への影響}

前述した流速デー夕の補正について, 効果と越波量の 出現頻度への影響について検討した．図-5はPIVより求 めた累積越波量（図中では「画像解析」と表記）と越波 妌により計測した累積越波量を比較した例である。越波 妌で求めた累積越波量は，妌内に越波水が着水した際に 生じる水面の振動により激しく振動している。このため 個別波の越波量を求めることは難しい。しかし，前述し たように，越波水の増加過程は妥当に得られている. PIVによる累積越波量は補正の有無により3つの結果を 示している，それらを比較すると，補正をしていない結 果は過大であるが，異常值を除く第1段階の補正により， 越波妌による累積越波量の中心を通るように修正されて いる．第2段階の補正による変化は小さく，異常值を取 り除くことで妥当な結果が得られることがわかる．別の

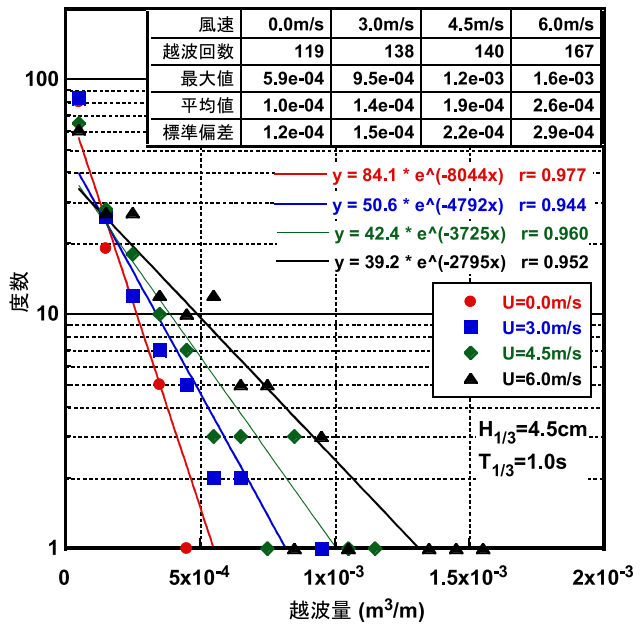

図-7 風による越波量出現頻度分布の変化 $\left(\mathrm{H}_{1 / 3}=4.5 \mathrm{~cm}, \mathrm{~T}_{1 / 3}=1.0 \mathrm{~s}\right)$

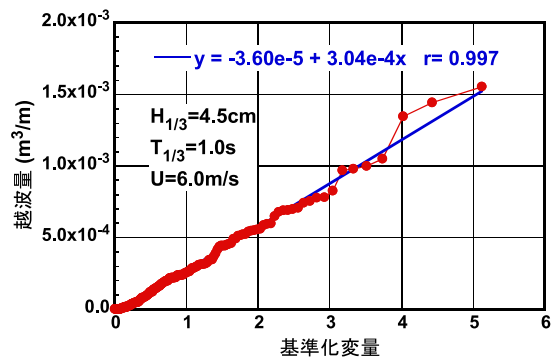

図-8 個別波の越波量の指数分布への適合性

言い方をすれば，累積越波量を基準にして流速を調整す る第2段階の補正が小さくて済むということは，元の流 速デー夕が妥当に得られていたと考えられ，その意味で 第2段階の補正量は可視化実験の成否の目安といえる. なお，眓中に示す越波流量をみると，当然であるが補正 によってほぼ一致している。図-6は，図-5の補正なしと 2段階補正後の結果について求めた越波量の出現頻度分 布である. 図-5で示したように，累積越波量に対しては 流速補正の効果が大きく見えるけれども，1波毎の越波 量に対する補正量は小さいため, 出現頻度の大きな变化 はない。このことから，流速の補正は越波量の出現頻度 には大きく影響しないといえる.

\section{3. 風作用下における越波量の出現頻度の特性}

図-7に, $\mathrm{H}_{1 / 3}=4.5 \mathrm{~cm}$ のケースについて個別波の越波量 の頻度分布を示す。縦軸は対数表示しており，また，図 中には平均越波量や標準偏差等の統計量も示している. 頻度分布は越波量が大きくなるほど頻度が減少しており, 既往の研究報告と同様の結果となっている．風速が大き くなるにつれて頻度分布の裾が広がり，大きな越波量の 発生頻度が増加して, 越波回数や平均越波量も増加して 

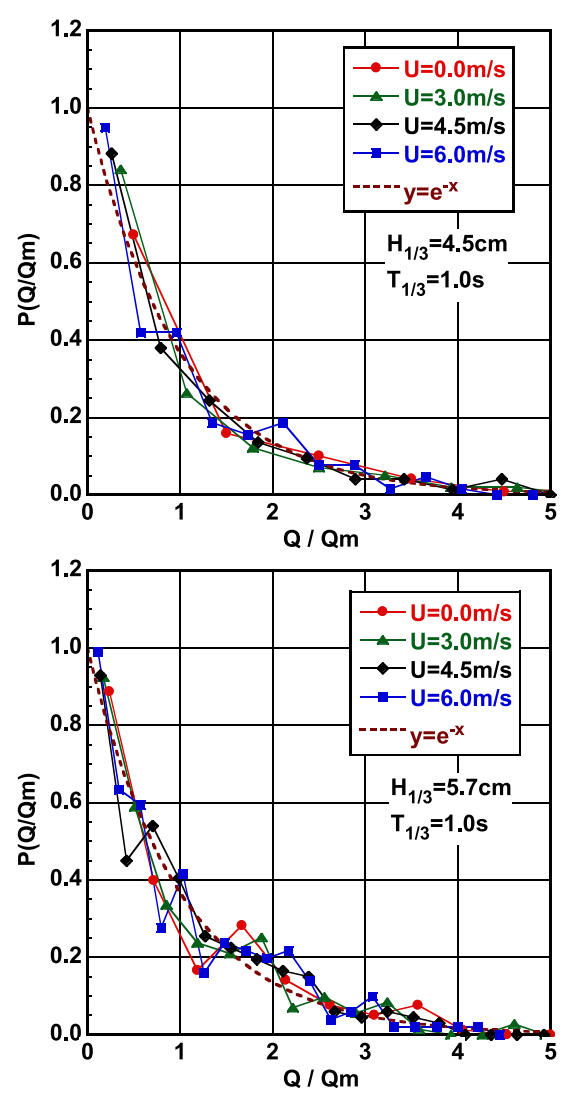

図-9 越波量の確率密度分布

いる. 図中に示すラインは指数関数による近似で, 泉宮 ら（2006）が述べたように，頻度分布は指数分布で表わ されるものと推測される.そこで, 図-8に示すように, 確率紙にプロットして, 越波量の指数分布への適合性に ついて調べたところ, 全てのケースでほぼ直線上にプロ ットされ，指数分布への適合性が高いことが示された。

図-9は図-7に示した出現頻度から求めた確率密度分布 である。ただし, 横軸は平均越波量で基準化している. なお, 越波量の基準化において, 位置母数については, 図-8に示す回帰式の切片が小さいことから0とした。ま た, 図中には期待值 1 の指数分布を破線で示している. 図より, $\mathrm{H}_{1 / 3}=5.7 \mathrm{~cm}$ のースで多少のばらつきがみられ るものの, 全てのケースで確率密度分布がよく一致して いる.すなわち, 風の影響により出現頻度は変化するが, 基準化した越波量に対する確率密度分布は期待值 1 の指 数分布に帰着する。このことは, 平均越波量のみで越波 量の出現確率が定まることを意味する.

平均越波量は風速に応じて変化している. 本研究では 直立堤で打ち上がる越波形態を対象としており, 風が作 用する場合，図-2にみられるように，打ち上がった波が 風圧で陸側に押されるために越波量が増加する. そこで,
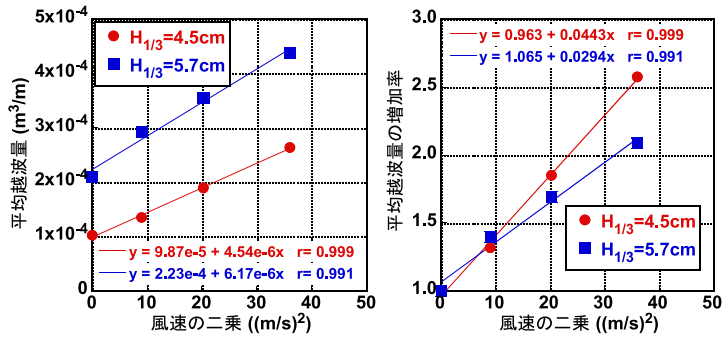

図-10 風速の二乗と平均越波量および増加率の関係

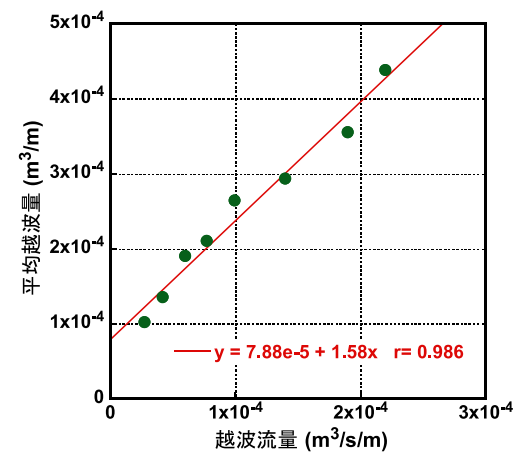

図-11 平均越波流量と越波流量の関係

図-10に風速の二乗に対する平均越波量の変化と無風時 の平均越波量に対する増加率を示した。図より平均越波 量は風速の二乗に比例することが確認できる. また, 波 高により平均越波量の増加率は異なり, 平均越波量が小 さい $\mathrm{H}_{1 / 3}=4.5 \mathrm{~cm}$ のケースで増加率が大きい.

\section{4. 平均越波量の推定}

平均越波量により越波量の出現頻度が定まることか ら, 平均越波量を推定することを考える. 通常の越波の 検討では, ある一定時間での平均量である越波流量を対 象とすることが多い。したがって, 越波流量から平均越 波量を推定できれば都合がよい. 図-11に平均越波量と 越波流量の関係を示す.このように, 両者には明確な比 例関係が認められる。 ところで, 平均越波量 $\mathrm{Q}_{\mathrm{m}}\left(\mathrm{m}^{3} / \mathrm{m}\right)$ は個別波の越波量の総和を越波した波の数 $\mathrm{n} て ゙$ 除したも ので, 越波流量 q $\left(\mathrm{m}^{3} / \mathrm{s} / \mathrm{m}\right)$ は個別波の越波量の総和を 継続時間 $\mathrm{NT}_{\mathrm{m}}$ （Nは作用した波の数， $\mathrm{T}_{\mathrm{m}}$ は平均周期 $(\mathrm{s})$ ) で除した時間平均量であるので，両者の関係は次のよう になる。

$$
Q_{m}=\frac{T_{1 / 3}}{\beta(n / N)} q
$$

ただし, 平均周期 $\mathrm{T}_{\mathrm{m}}(\mathrm{s})$ は係数 $\beta$ を用いて, より利用し やすい有義波周期 $\mathrm{T}_{1 / 3}(\mathrm{~s})$ に変換している. なお係数 $\beta$ は スペクトル形に依存して変化するが, 概ね $\beta=0.9 \sim 1.4$ とされている（合田，2008）。また，n/Nは越波率である. 式（1）より, 越波流量から平均越波量を推定するには 


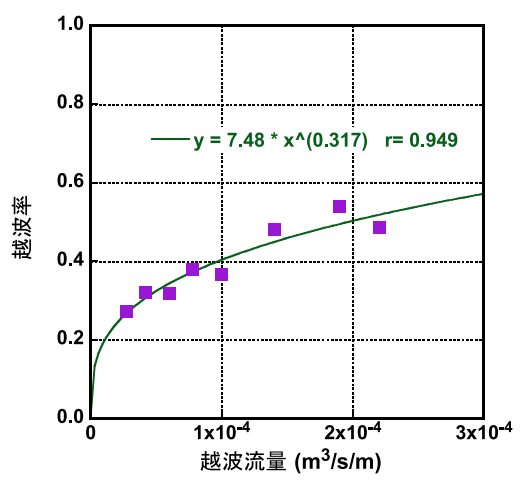

図-12 越波流量と越波率の関係

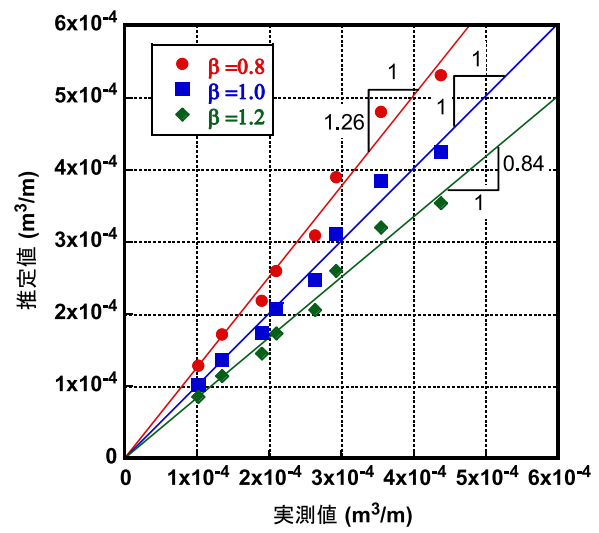

図-13 平均越波量の推定值と実測值の比較

越波率が必要となる。越波率については，井上ら（1989， 1990）やVictorら（2012）により，相対水深や相対天端 高などとの関係が検討されているが，風速の影響は不明 である．簡単に越波流量との関係をみてみると図-12の ようになり，越波流量の累乗で概ね近似できるようであ る。そこで, 図-12の近似式で越波率を推定し, 式（1） により越波流量から平均越波量を求めて実測值と比較す ると図-13のようになった。ただし，図の推定值は有義 波周期と平均周期の換算係数 $\beta$ を $0.8,1.0,1.2$ とした場 合について算定している。図より，本実験の結果との比 較では $\beta=1.0$ とした場合に精度よく平均越波量を推定で きている.

\section{5. おわりに}

本研究では，造波風洞水路により不規則波と風を同時 に作用させた越波の実験を行い，画像解析を用いた越波 量の計測手法により個別波の越波量を計測し，風作用下 における越波量の出現頻度について検討した。 その結果, 越波量の出現頻度は風により変化するが, 平均越波量で 基準化した越波量に対する確率密度分布は期待值 1 の指 数分布に帰着することが示された。したがって，越波の
出現確率は平均越波量のみで定まる。平均越波量に対す る風の影響は明確であり，平均越波量は風速の二乗に比 例して増加する。また，越波率や有義波周期と平均周期 との比率について検討の余地があるが，それらを用いて， 越波流量から平均越波量を推定できることを示した。し たがって，例えば，越波流量を模型実験で調べた際に， その越波流量から平均越波量を推定でき, さらに, 越波 の出現頻度を知ることができる.

本研究では，直立堤で波が打ち上がる越波を対象とし た。この越波形態の場合，越波量に風が強く影響する. 一方，例えば消波護岸で越流する越波形態では，風の影 響は相対的に小さい. しかし, 本研究で得られた越波の 出現頻度に関する特性そのものは, 護岸の構造形式を問 わず当てはまるものと期待される.

また，本研究では，越波の出現頻度に対する風の影響 について模型実験を行ったが，越波の実験における風速 の相似則が不明という問題が依然として存在しており, 現状では，実験結果から現地での越波に対する風の影響 を定量的に評価することは難しい. 今後は，これまでに 得られた知見をもとに，越波実験における風速の相似則 に関する検討が必要である。

謝辞 : 本研究は科学研究費補助金（課題番号：22686047） の助成を受けたものである．ここに記して謝意を表する.

\section{参 考 文 献}

泉宮尊司・濱田良平・石橋邦彦（2006）：消波護岸の越波流量 の確率分布特性に関する研究, 海洋開発論文集, 第 53 巻, pp. 716-720.

泉宮尊司（2009）：消波護岸の越波流量の確率分布の理論的推 定とその適用性に関する研究, 海洋開発論文集, 第 25 巻, pp. 563-568.

井上雅夫・島田広昭・殿最浩司（1989）：不規則波における越 波量の出現分布特性，海岸工学論文集，第36巻，pp. 618622.

井上雅夫・島田広昭・殿最浩司（1990）：不規則波による緩傾 斜護岸の越波特性，海岸工学論文集，第 37 巻，pp. 514518.

合田良實（2008）：耐波工学－港湾・海岸構造物の耐波設計, 鹿島出版会, $430 \mathrm{p}$.

山城 賢・村上邦宏・吉田明徳（2012a）：画像解析を用いた 水理模型実験における越波量計測, 土木学会論文集 B3 (海洋開発), Vol. 68, No. 2, pp. I_324-I_329.

山城 賢·改田将平・村上邦弘・吉田明徳 (2012b) : 水理模 型実験における画像解析を用いた越波量計測手法の有用 性について, 土木工学論文集 B2（海岸工学）, Vol.68, No.2, pp.I_736-I_740.

Franco, L., M. de Gerloni and J. W. van der Meer (1994) : Wave overtopping on vertical and composite breakwaters, Proc. 24th ICCE, pp. 1030-1044.

Victor, L., J. W. van der Meer and P. Troch (2012) : Probability distribution of individual wave overtopping volumes for smooth impermeable steep slopes with low crest freeboards, Coastal Engineering, Vol.64, pp. 87-101. 